
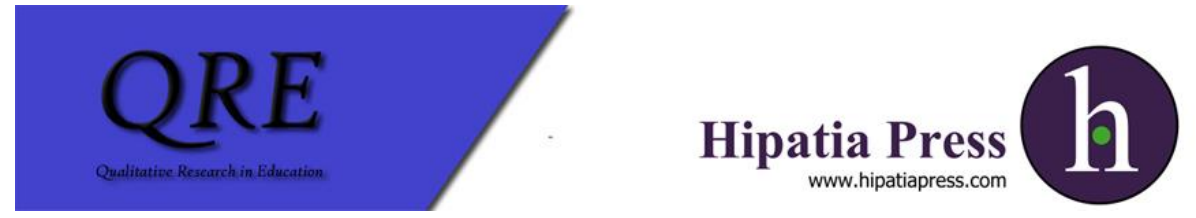

Instructions for authors, subscriptions and further details:

http://qre.hipatiapress.com

\title{
An Analysis of Children's Right to Participation at Primary Schools in Turkey: A Case Study
}

Ahmet Kılıç ${ }^{1}$ \& Ayşe Öztürk ${ }^{2}$

1) Vocational School of Health Services, Bozok University, Turkey.

2) Department of Primary Education, Gaziantep University, Turkey.

Date of publication: October $28^{\text {th }}, 2018$

Edition period: October 2018 - February 2019

To cite this article: Kilıç, A., \& Öztürk, A. (2018). An analysis of children's right to participation at primary schools in Turkey: a case study. Qualitative Research in Education, 7(3), 265-303. doi:10.17583/qre.2018.3528

To link this article: $\mathrm{http}: / / d x . d o i . o r g / 10.17583 /$ qre.2018.3528

\section{PLEASE SCROLL DOWN FOR ARTICLE}

The terms and conditions of use are related to the Open Journal System and to Creative Commons Attribution License (CC-BY). 


\title{
An Analysis of Children's Right to Participation at Primary Schools in Turkey: A Case Study
}

\author{
Ahmet Kılıç \\ Bozok University
}

\author{
Ayşe Öztürk \\ Gaziantep University
}

(Received: 02 June 2018; Accepted: 25 October 2018; Published: 28

October 2018)

\section{Abstract}

This research attempted to explore to what level children's right to participation was realized at a primary school which is highly qualified in terms of children's rights in Turkey. The study was designed as a case study. The study group of the research was chosen via critical case sampling. The data were gathered through observations, interviews and document analysis. The data were analyzed by conducting content and descriptive analysis. In the research, children's right to participation related 15 different contexts, of which three were laws, were determined at the primary school which is highly qualified in terms of children's rights. It was revealed that the realization level of children's right to participation changed in different classrooms based on teachers' attitudes and beliefs. The results of the research demonstrated that there was a difference in children's right to participation at the primary school which is highly qualified in terms of children's rights ranging from the level at which children were not involved to the level at which children participated in decision-making processes.

Keywords: children's participation, children's rights, level of children's participation, children's participation at school, case study 


\section{El Nivel de Efectuación del Derecho a la Participación de Los Niños en Las Escuelas Primarias en Turquía: Un Estudio de Caso}

Ahmet Kılıç

Bozok University
Ayşe Öztürk

Gaziantep University

(Recibido: 02 de junio de 2018; Aceptado: 25 de octubre de 2018; Publicado: 28 de octubre de 2018)

\section{Resumen}

Esta investigación examinó el nivel de efectuación del derecho a la patricipación de los niños en una escuela primaria calificada de alta cualidad en términos de los derechos infantiles en Turquía. El estudio fue diseñado como un estudio de caso. El grupo de estudio de la investigación fue determinado con el muestreo de situación crítica. En la investigación, los datos fueron obtenidos a través de los métodos de observación, entrevista y análisis de documentos. Los datos, fueron analizados mediante análisis de contenido y descriptivo. En la investigación, el derecho a la participación de los niños se relacionó con 15 contextos diferentes, de los cuales, tres de ellos fueron con recursos legales relacionados con el derecho a la participación de los niños en la escuela primaria que está altamente calificada en términos de los derechos de los niños. Se reveló que el nivel de realización del derecho de los niños a la participación era diferente en función de las actitudes y creencias de los maestros. Los resultados de la investigación demostraron que había una diferencia en el derecho de los niños a la participación en la escuela primaria que está altamente calificada en términos de los derechos de los niños que van desde el nivel en el que los niños no participaron hasta el nivel en que los niños participaron en los procesos de toma de decisiones.

Palabras clave: participación de niños, derechos de niños, nivel de participación de los niños, participación de los niños en la escuela 


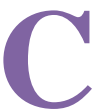

hildren's right to participation took place in the UN CRC for the first time (Flowers et al., 2009). In this sense, Article 12 of the convention entitles every child who has the capability to develop a certain standpoint to freely express his/her ideas regarding any issues and make his/her voice heard in any legal or administrative proceeding concerning them, and it requires contracting countries to pay sufficient attention to children's ideas based on their age and maturity level (Hodgkin \& Newell, 1998). Furthermore, the Articles 13, 14, 15, 17, 23, 29 and 31 are closely related with children's right to participation. Within the context of these articles, children's right to participation is elaborated in terms of expression of ideas, freedom of religion and consciousness, establishing associations, accessing information, participation in games, entertainment, cultural and artistic activities, environmental protection and sustainable development (Hart,1997). Children's right to participation is of utmost importance in terms of students' active participation in the learning process, quality learning outcomes, positive ego development, enhancement of school commitment, and cultivation of democratic values (Davies, Williams, Yamashita, \& Ko Man-Hing, 2006; Osler \& Starkey 2005; Roberts, 2003). In addition, children's right to participation makes contributions to children's being participative citizens who adopt democratic values in the long run (Miller, 1997; Pascal \& Bertram 2009). However, a classroom or school culture in which children's right to participation is ensured is rarely observed across the world (Lansdown, Jimerson, \& Shahroozi 2014). Some of the problems encountered in this process can be listed as follows. First of all, it is a fact that children's right to participation will be realized before governments make arrangements to put the necessary regulations, policies, and practices into effect. On the other hand, adults' common views regarding the fact that children do not have sufficient capacity to participate in decision-making processes constitute another obstacle to the realization of this right (Lansdown, 2010; Raby, 2014). On the other hand, teachers' inadequacies with regard to children's rights and the fact that they perceive them as a threat for classroom control constitute an obstacle for implementation of children's rights (Howe \& Covell, 2007). Accordingly, it can be said that their inadequacies on how to implement children's right to participation (Rudduck \& Flutter, 2000) and the fact that children's right to participation is perceived as a threat since it destroys the authority of adults (Raby, 2014) 
constitute significant problems for the implementation of this right. Furthermore, authoritarianism, discrimination, and violence are commonly going on in schools in many countries. This emerges as a significant obstacle for children to express their opinions and to listen to their views and thus to ensuring their right to participation (Lansdown et al., 2014). For various reasons like these, there are problems in the implementation of children's right to participation in the education process. This situation has led politicians to make legal regulations and researchers to conduct studies regarding children's right to participation.

In this regard, researchers have conducted various studies on children's right to participation. To mention some of the research, for example, Horgan, Forde, Martin and Parkes (2017) examined children's right to participation in terms of family, social and school life. Lansdown et al. (2014) explained children's right to participation theoretically. Gilleece and Cosgrove (2012) investigated female and male students' civic participation levels in the schools in Ireland. Hart (1997) identified eight steps pertaining to participation levels in his model which resembles a ladder. Shier (2001) specified five phases of participation in his model on children's right to participation. Synodi (2014) examined children's right to participation in the research conducted on kindergartens in Greece. Habashi, Driskill, Lang, and De Falco (2010) attempted to investigate 179 UN member countries' constitutions in terms of living, protection, and right to participation. Consistently, Moore and Kirk (2010) reviewed the literature on children's and young people's participation in decision-making processes about health. Cotmore (2003) examined 7-11 years old students' active participation in parliament studies. Smith (2007) reviewed the literature on applied research regarding children's right to participation. Burger (2018), in his study, aimed to examine how public primary school students evaluate the significance of their participation rights and whether these evaluations change in terms of perceived discrimination in the school environment. In their research, Koran and Avc1 (2017) investigated pre-school teachers' practices in terms of children's participation rights and determined negative and positive applications for children's participation rights. Perry-Haza (2016) investigated patterns of children's participation in public policymaking and defined adults' reactions for children's participation in Israeli. In her study, Öztürk (2017), analysed life sciences curricula in terms of children's participation rights with a historical perspective in Turkey. In 
another study, Lloyd and Emerson (2017) investigated the nature of the relationship between wellbeing and participation rights. Tozduman Yaral1 and Güngör Aytar (2017), investigated children's participation rights in preschool education practices according to the views of teachers and children. With a capability approach, Hart and Brando (2018) investigated how children's wellbeing and participation rights can be developed and supported in educational settings. When these studies are examined, it can be suggested that they focused on construction of theoretical knowledge base on children's right to participation, the quality of the realization of children's right to participation and identification of the shortcomings, examining the practices for children's right to participate in different educational contexts and public policymaking process, analysis of the curriculum in terms of children's participation rights.

On the other hand, schools at which educational policies of the countries are embodied are highly significant in order for effective realization of children's right to participation. In this sense, realization of children's right to participation requires schools to be turned into democratic centers, the generation of opportunities to inform students, and the implementation of educational policies and regulations (Lansdown, 2011). In Turkey too, some legal regulations such as the practices of students' council at schools and ensuring children's participation in organizations and commissions at schools are enacted by the Ministry of National Education for the realization of children's right to participation. At the same time, schools can also form opportunities to realize children's right to participation within the context of their latent curricula. In order for these practices to be effective, it is needed to make analyses about the operational process during the implementation. Therefore, conducting a related study can reveal information about the quality of the arrangements made for children's right to participation at classroom and school level, unearth the shortcomings and gather information about whether legal regulations about children's right to participation are realized in real life. For this reason, it is also significant to investigate the level to which children's right to participation is enacted in a primary school which is highly qualified in terms of children's rights. A school which is qualified in terms of children's rights refers to a school culture where the UNCRC is implemented and children are taught their rights and made to experience them in practice. In this context, it is important to carry out protective and supportive studies and to bring the 
teaching-learning process, school rules, communication processes in the school, relations and physical environmental arrangements into compliance with children's rights in a school environment based on children's rights (Öztürk \& Doğanay, 2017). Furthermore, the schools where children's rights are implemented are democratic environments where children apply citizenship values. Accordingly, children are significantly regarded as rights holders and citizens. These values are reflected in education programs in all grades with subjects, school policies and practices, school mission and codes of behavior. These practices improve citizenship practices in democratic schools, and a positive values system is created for better social values, mutual respect and learning in the school (Covell, Howe, \& McNeil, 2010). In this process, it is of great importance to provide children with knowledge and skills for effective democratic citizenship (Howe \& Covell, 2010) and to implement children's right to participation (Hodgkin \& Newell, 1998; Lansdown et al., 2014). Within the context of children's right to participation, various applications, such as the establishment of school councils, children's councils, school and classroom rules with students, school newspapers, students' participation in decision-making processes related to themselves, the fact that children are a part of decisionmaking processes in the school, active participation in educational issues, giving responsibility and giving an opportunity to make a decision, are expected to be implemented in these schools (Flowers et al., 2009; Hodgkin \& Newell, 1998; Lansdown et al., 2014). The results obtained through an evaluation carried out in the primary school which is highly qualified in terms of children's rights chosen via critical case sampling technique may provide the opportunity to make logical inferences about the level to which children's right to participation is enacted in other primary schools which are not highly qualified in terms of children's rights (Patton, 2002). Such an evaluation can provide in-depth information about the best practices about children's right to participation in Turkey, the variety of the arrangements in this direction, their quality, and shortcomings. Moreover, it is thought that this research can provide data for comparative studies about children's right to participation to be conducted at the international level. In the light of the aforementioned reasons, this study aimed to examine the level to which children's right to participation was enacted in a primary school which is highly qualified in terms of children's rights. In line with this main aim, answers were sought to the following questions: 
What kinds of arrangements are made for the improvement of children's right to participation in a school the children's rights-based structure of which is high? What is the level of realization of children's right to participation in a school the children's rights-based structure of which is high?

\section{Method}

\section{Research Model}

This research examined the level of realization of children's right to participation in a primary school which is highly qualified in terms of children's rights in Turkey, and it was designed as a case study (Patton, 2002). The case study enables to obtain holistic and meaningful features about real-life events (Yin, 2009). In this research, it was aimed at cultivating an understanding about how a highly qualified implementation can be in order for the realization of children's right to participation through a case study. Data were collected via observations, interviews and document analysis.

\section{Study Group}

The study group of the research was selected by using critical case sampling which is a purposeful sampling technique (Patton, 2002). In this sampling method, the situation that will give the furthest information is selected, and the information is aimed to be applied to other situations at the maximum level. According to the information obtained here, if a situation is correct here, it is likely to be correct in all other situations. This sampling technique allows the researcher to make logical inferences that if an event or problem occurs at a place, it is likely to occur anywhere, or vice versa (Patton, 2002). In this sense, examining the level to which children's right to participation is realized at the primary school which is highly qualified in terms of children's rights may make a contribution to developing an understanding about how a highly qualified sample implementation can be for children's right to participation at the primary school level in Turkey. This is because, in a school which is highly qualified in terms of children's rights, the arrangements made for children's right to participation are also 
expected to be highly qualified. In democratic societies, the implementation of children's right to participation and upbringing of them as participatory citizens are common values shared in such schools. Accordingly, it is expected that this value will be reflected in the school's education policy and school culture and that qualified arrangements will be made for children to learn by experiencing the right to participation. From this point of view, information to be obtained by examining a school which is highly qualified in terms of children's rights in Turkey will give information on how a practice with a good quality in terms of children's rights in Turkey could be, in which dimensions arrangements are made for the right to participation, and the level of realization of the right to participation. Based on this information, an opportunity to make two different logical inferences will be provided. The quality of the realization of children's right to participation in schools of a similar nature in Turkey will also most probably have similar characteristics to those of this school. On the other hand, if problems related to the implementation of children's right to participation are experienced, or it cannot be implemented at high levels in such a school, these problems are likely to be experienced in all other groups. In line with the aim of the study, children's rights-based structures of all primary schools (there are a total of nine primary schools) in Sivas, Kangal were examined to determine the school which is highly qualified in terms of children's rights. To this end, Children's Rights-Based School Scale (CRBSS) (Öztürk \& Doğanay, 2017) was administered at nine primary schools located in the Kangal district of Sivas province. The averages of the scores obtained by these schools from the CRBSS were statistically calculated. Among these schools, the primary school which obtained the highest score on CRBSS (X: 4.38, sd: .04) was determined to be the study group of the study.

The primary school which is highly qualified in terms of children's rights is a singled floor school which had $1^{\text {th }}, 2^{\text {th }}, 3^{\text {th }}$ and 4th-grade level classrooms. There were 22 students including 12 girls and 10 boys at the first-grade level. The ages of these students ranged from 6 to 7 years. There were 24 students including 8 girls and 16 boys at the second-grade level. The ages of these students ranged from 7 to 8 years. There were 21 students including 7 girls and 14 boys at the third-grade level. The ages of these students ranged from 9 to 10 years. There were 18 students including 7 girls and 11 boys at the fourth-grade level. The ages of these students ranged 
from 11 to 12 years. Most of the students belonged to middle-income families, and the number of siblings ranged between 3 and 4 . There were a projection and a computer in each classroom. The school building and garden were observed via a camera. There were playgrounds in the garden. Most of the mothers graduated from primary education $(62.5 \%)$, and more than half of the fathers were high school graduates $(50.7 \%)$. The school principal held a graduate degree and had 9 years of professional experience. The assistant principal had 8 years of experience, and teachers had 6 years and above professional experience.

\section{Data Collection Tools}

\section{Children's rights-based school scale (CRBSS)}

In order to identify the primary school which is highly qualified in terms of children's rights, Children's rights-based school scale (CRBSS) (Öztürk \& Doğanay, 2017) was used. The results of the EFA demonstrated that CRBSS had five factors including 26 items and that the five factors explained $76.823 \%$ of the total variance. Of the CFA fit indices, GFI (.90), AGFI (.88) and NFI (.91) were seen to be at satisfactory level and X2/sd(CMIN/df) (1.722), CFI (.96), IFI (.96), RMSEA (.045) and SRMR (.030) fit indices were found to be at perfect level. Cronbach's Alpha coefficient regarding the whole scale was found to be 924 . The CRBSS was employed in this study following the reliability study. Cronbach's Alpha coefficient was found to be .87 in this study. The sub-factors of the scale were created as protection-support, teaching-learning process, relations-communication, environmental arrangements, and rulescooperation. The items aimed at receiving students' opinions on all issues related to students, ensuring that students can share their requests and complaints with their administrators and teachers whenever they want, receiving students' opinions in the process of creating rules in the school, and establishing physical conditions for students to perform leisure time, recreational, game, artistic and sporting activities in the school, with respect to children's right to participation, are within the scope of these factors. 


\section{Unstructured observation (Camera records)}

Observations were made in the classrooms, the school and ceremonies; and these were recorded via a camera in order to collect information about the realization level of children's right to participation at the primary school which is highly qualified in terms of children's rights. The data were thoroughly collected via the camera records, and thus these were used as data sources to prevent researcher bias and benefit from them in the reliability study. Within the scope of the study, 3-hour observation was performed in a week for 8 weeks in four classes in the school. Furthermore, observations were made for student participation in the ceremonies conducted for specific days and weeks (Traffic and first aid week and Environmental protection week) in the school and in the organizations of April 23 National Sovereignty and Children's Day events.

\section{The interview form used for school administration for children's right to participation (IF-1)}

IF-1 was prepared and used in the study to gather information school administration's views and the activities organized for children's right to participation. IF-1 was developed based on the examination of theoretical knowledge and research on children's right to participation, the Ministry of National Education's arrangements regarding children's right to participation at primary school level and the views of field specialists having expertise in children's rights education and of teachers. In line with this information, 10 open-ended items regarding the arrangements about children's right to participation to be carried out at primary school level were developed. These items were given to two faculty members working on children's rights education for consulting their views. Based on the feedback taken from the faculty members, required arrangements were made in the IF-1, and thus it took its final form after the pilot implementation. 


\section{The interview form used for teachers for children's right to participation (IF-2)}

In the research, the IF-2 was prepared and used in order to collect information about classroom teachers' views about children's right to participation and the activities they carried out. Similar processes were followed in the development of the IF-2 like IF-1. After the development process, a form including 12 items which could reveal the arrangements made and the quality of these arrangements was constructed.

\section{The interview form used for students for children's right to participation (IF-3)}

IF-3 was developed and used to reveal the quality of the arrangements made for children's right to participation and observe the process from the eyes of the students in the research. The IF-3 incorporates three parts prepared with different purposes. The first part of the IF-3 was developed to determine the level of realization of children's right to participation in the commissions from the eyes of the students taking part in the commissions at the primary school which is highly qualified in terms of children's rights. With the questions in this part, how students were selected to the commissions and whether their views were considered in the commissions was attempted to be unearthed. This part of the IF-3 was applied to three students affiliated with these commissions. The second part of the IF-3 was prepared to observe the realization level of children's right to participation in the teaching-learning processes in the classrooms from the perspectives of the students. The questions in this part aimed at revealing whether the arrangements regarding children's right to participation were incorporated in the teaching-learning practices in the classrooms and children's views were cared for in this process or not. In this sense, interviews were conducted with two students randomly selected from among the students at all classroom levels. The third part of the IF-3 was developed to collect information about the operation of the studies of the students' council and the realization level of children's right to participation in extracurricular activities. Therefore, interviews were conducted with five students, of whom three students took active roles in social activities. The IF-3 was prepared by following similar steps in the development of IF-1 and IF-2. 


\section{Printed documents}

In the research, printed documents were also examined in order to determine the realization level of children's right to participation at the school. For this reason, the reports regarding the general meeting of teachers held at the beginning of the academic year, the students' council at the school, the executive committee on guidance and psychological counseling services and the social activities commission, weekly lesson timetables, the minutes of April 23 National Sovereignty and Children's Day celebrated at the school and some documents about certain days and weeks were investigated.

\section{Data Collection}

The data regarding the realization level of children's right to participation at the school were gathered in an interval of two months in the present research. Unstructured observations were carried out for eight weeks, three hours each week in the classrooms. The school was also observed in lesson breaks. The data were obtained from school administration, teachers and students by means of semi-structured interviews. During the interviews, it was first assured that the names of the participants would be kept confidential and their permission was taken for recording the interviews. The printed documents were taken from the school administration.

\section{Analysis of the Research Data}

In the data analysis process, observation data, interview data and printed documents were brought together, and transcripts were constructed. A twostep process was used in the analysis of the transcripts. In the first phase, the data set was content-analyzed in terms of children's right to participation. In this process, open and selective coding processes which are the first phase of content analysis (Strauss \& Corbin, 1990) were pursued. In this sense, the transcripts were analyzed line by line, and thus the codes regarding children's right to participation were constructed based on direct or indirect meanings. These codes were named by examining the relevant literature. Consequently, 15 codes about the arrangements related with children's right to participation were constructed. 
In the second phase, descriptive analysis was conducted in order to determine the realization level of children's right to participation. Prior to descriptive analysis, the data set was reorganized. In the reorganization, the diverse data collected from different sources regarding each code were incorporated. Thus, the information reflecting the related issue was incorporated in different perspectives, and data units were formed. For example, data on children's participation in students' council were obtained from interviews conducted with the school principal, deputy principal, school student representative, and a randomly selected student in the school, and from written documents. During the analysis process, all data for the relevant code were brought together and used in the descriptive analysis process. In this process, it was allowed to observe and compare the level of realization of the right to participation for the relevant code from different perspectives.

In the research, Shier's (2001) five-pathway participation model was used for descriptive analysis. In the formation process of the analysis framework, a new participation level which was not involved in Shier's model was added. In this way, a descriptive analysis framework which was made of six levels and ranged between 0 and 5 was developed (It is presented in Table 1).

Table 1

The Descriptive Analysis Framework Based on Shier's Model

\begin{tabular}{ll}
\hline Participation levels (PL) & Explanations \\
\hline Level 0 (L0) & $\begin{array}{l}\text { Children are not involved in the process under no } \\
\text { circumstances. } \\
\text { Level 1 (L1) }\end{array}$ \\
Children can express their ideas if they want \\
(However, they are not encouraged to come up with ideas) \\
Level 2 (L2) \\
Children are encouraged to express their ideas \\
(participation) \\
Level 3 (L3) \\
Children's ideas are paid attention to \\
(Children's ideas are paid attention to in the decision- \\
making process) \\
Children participate in the decision-making process \\
directly \\
Children share power and responsibility in the decision- \\
making process
\end{tabular}


At each level of participation, there may be varying levels of the contributions made by individuals and organizations for strengthening the process. In this regard, Shier identified three phases of participation in the realization of the five levels. These are opening, opportunity, and obligation. In the opening phase, organizations or individuals specify that they are ready to make arrangements in order for ensuring children's participation. In the opportunities phase, procedures are prepared and implemented for the realization of children's right to participation. Lastly, in the obligations phase, the realization of children's right to participation is compulsory as a policy requirement. Within the scope of the study, in addition to these, a new phase, "non-existent phase", in which they do not specify that they are ready in the arrangement process was added. At the end of the analysis process, a structure which determined the realization level of children's right to participation was developed through the incorporation of the content and descriptive analysis data. The sample structure is presented in Table 2 .

\section{Table 2}

The Arrangements regarding Children's Right to Participation and the

Realization Level of Children's Right to Participation (A sample structure for analysis $)^{l}$

The arrangements regarding children's right to participation
Information regarding the realization level of children's right to participation

PL

APC

$\begin{array}{lllllllllll}\text { LO } & \text { L1 } & \text { L2 } & \text { L3 } & \text { L4 } & \text { L5 } & & \text { NE } & \text { OP } & \text { O } & \text { LO }\end{array}$

Children's participation in

students' counci

When Table 2 is examined, it may be argued that ensuring children's participation in students' council at the primary school which is highly qualified in terms of children's rights was a legal obligation and that the views of the representative of the students' council were taken into consideration in the decision-making process. 


\section{The Study of Reliability and Validity in the Research Process}

The following studies were conducted in order to ensure reliability and validity in the research:

Camera records were used to prevent the loss of the data. The data were obtained from different sources by using different methods, and whether the data were consistent or not was examined through comparisons. The data were collected in a long interval of two months. The researchers questioned their role and whether they acted with bias during all implementations in the research process. The study group and the setting in which the research was conducted were described in detail. The coding done for ensuring the reliability of the results of the analysis was presented to an expert (Miles \& Huberman, 1994). Agreement and dissidence were determined between the codes specified by the researchers and the external coder specialized both in children's rights education and qualitative data analysis. In addition, the codes involving dissidence between the coders were discussed and agreed.

\section{Results}

The results regarding the arrangements made for children's participation in decision-making at the primary school which is highly qualified in terms of children's rights are given in Table 3.

Table 3

The Arrangements regarding Children's Right to Participation and the Realization Level of Children's Right to Participation ${ }^{1}$

The arrangements regarding children's right to Information regarding the realization level of children's right to participation participation

PL

APC

$\begin{array}{llllllllll}\text { LO } & \text { L1 } & \text { L2 } & \text { L3 } & \text { L4 } & \text { L5 } & \text { NE } & \text { OP } & \text { O } & \text { LO }\end{array}$

Children's participation in the

executive committee on

guidance and psychological

counseling services

Children's participation in students' council 
Table 3

The Arrangements regarding Children's Right to Participation and the Realization Level of Children's Right to Participation (continuation)

The arrangements regarding children's right to participation

Information regarding the realization level of children's right to participation

PL

APC

$\begin{array}{lllllllllll}\text { LO } & \text { L1 } & \text { L2 } & \text { L3 } & \text { L4 } & \text { L5 } & \text { NE } & \text { OP } & \text { O } & \text { LO }\end{array}$

Children's participation in the social activities commission Children's participation in the formation of homework L0: 1st, 2nd, 4th, 3rd grades *Children's participation in the formation of weekly lesson timetables L0:2nd, 4th grades; L3: 3rd, 1 st grades

*Students' participation in the preparation of classroom bulletin boards LO: 1st grade; L3: 3rd 4th grades;

L4: 2nd grade

Students' participation in the construction of classroom rules

LO: 1st grade; L4: 2nd, 4th, 3rd grades

Students' participation in the planning of the free activities course

L4: 1st, 2nd, 4th, 3rd grades Children's participation in the formation of school bulletin boards and the board of interesting ideas 
Table 3

The Arrangements regarding Children's Right to Participation and the Realization Level of Children's Right to Participation (continuation)

The arrangements regarding children's right to participation

Information regarding the realization level of children's right to participation

PL

APC

$\begin{array}{lllllllllll}\text { L0 } & \text { L1 } & \text { L2 } & \text { L3 } & \text { L4 } & \text { L5 } & & \text { NE } & \text { OP } & \text { O } & \text { LO }\end{array}$

- Children's participation in the formation of the board of interesting ideas

L4: 1st, 2nd, 4th, 3rd grades

- Children's participation in the formation of school bulletin boards

L3: 1st, 2nd, 4th, 3rd grades

Children's participation in the formation and organization of playgrounds

L0: 1s, 2nd, 4th, 3rd grades

Children's participation in the planning of the ceremonies

- April 23 National

Sovereignty and Children's

Day ceremony

L4: 2nd, 4th, 3rd grades

L0: 1 st grade

- Ceremonies for specific days and weeks

L3: 2nd, 4th, 3rd grades

L0: 1 st grade

Children's participation in the formation process of school rules

L0: 1st, 2nd, 4th, 3rd graders

(continues) 
Table 3

The Arrangements regarding Children's Right to Participation and the

Realization Level of Children's Right to Participation (continuation)

The arrangements regarding

children's right to

participation

Information regarding the realization level of children's right to participation

PL

APC

$\begin{array}{llllllllll}\text { LO } & \text { L1 } & \text { L2 } & \text { L3 } & \text { L4 } & \text { L5 } & \text { NE } & \text { OP } & \text { O } & \text { LO }\end{array}$

Children's participation in the

organization process of

teaching-learning activities

L0: 1st, 2nd, 4th, 3rd grades

Students' participation in the

decision-making process with

regards to the issues

concerning themselves

L0: 1st, 2nd, 4th, 3rd grades

Children's participation in

environmental protection and

sustainable development

L3: 1st, 2nd, 4th, 3rd grades

Table 3 demonstrates that 15 different contexts related children's right to participation were identified at the primary school which is highly qualified in terms of children's rights. These findings are presented phase by phase.

\section{Children's Participation in the Executive Committee on Guidance and Psychological Counseling Services}

In the research, it was detected that the executive committee on guidance and psychological counseling services was founded due to a legal obligation and that one student was involved in the commission at the primary school which is highly qualified in terms of children's rights. It was observed that students were selected to the executive committee on guidance and psychological counseling services based on their academic achievement and the suggestion of teachers. The printed documents and interviews demonstrated that the executive committee on guidance and 
psychological counseling services was founded at the beginning of the academic year and that the commission did not convene after its foundation. Furthermore, there was no evidence verifying whether the student selected to the commission had taken an active role in this process or not. It was revealed that this situation stemmed from school administration's beliefs and attitudes. Both the school principal and the assistant principal noted in the interviews that this commission did not have a workable structure at primary school level and that they did not consider the participation of children to the commission to be functional. This was stated by the assistant principal as: "These commissions are not generally very active for primary schools... we do not ask students' views. I have not seen such a thing until today... Every teacher makes his/her plan... there is nothing to do with children..."

When all of these results are considered together, it may be suggested that children's participation in the executive committee on guidance and psychological counseling services remained on paper and that the realization level of children's right to participation was "LO" and the arrangement level was "legal obligation".

\section{Children's Participation in Students' Council}

It was detected in the research that the students' council was founded due to a legal obligation at the primary school which is highly qualified in terms of children's rights. In the foundation process of the students' council, first of all, the student representative of the classroom was selected, and the students nominated for the presidency of the school council participated in the elections for the presidency of the school council. Furthermore, it was ensured that all of the students participated in the elections, and the candidates for being classroom and school representatives were determined based on students' views.

The investigations carried out in the research showed that the representative of the students' council was actively involved in the process and that students' views were taken into consideration. The assistant principal stated this situation as follows:

“... We help them to express themselves as there are things they want...we try to do these things if they express them in a good way 
and they are logical. For example, they wanted a library from us... we established a small library. This happened because of children's desire" (The Assistant Principal).

The representative of the students' council noted that the views they expressed in the council were paid attention to by the school administration and classroom teachers: “... our teachers listen to us. I can say what my friends want to the principal. We can say everything clearly. They do them..." (S1). Another student randomly chosen form the school commented on the operation of the SC as follows: "If there is something I want, I say this to him (to the student representative of the school) ... and he says this to teachers and the principal. The principal does some of what students ask..." (S2). When the explanation is examined, it can be argued that students communicated what they wanted to the representative of the students' council, and he reported these to the school administration. The school administration took students' desires into consideration.

The results obtained revealed that the students' council functioned actively at the primary school which is highly qualified in terms of children's rights, students' participation was ensured in the council and what students stated was evaluated and put into practice. In this sense, it can be suggested that the realization level of children's right to participation in the students' council was "L3", and the arrangement phase was "Legal obligation".

\section{Children's Participation in the Social Activities Commission}

In the research, it was found out that the social activities commission was founded at the primary school which is highly qualified in terms of children's rights as a legal requirement and three students were involved in the commission. It was determined that these students were chosen from among successful students by teachers. Interview data and printed documents indicated that the social activities commission did not operate actively at the school. When the reason why the social activities commission did not operate actively at the school and the participation of students were not ensured was examined, it was seen that the school administration did not believe that this commission could work at primary school level and that children could not state their views about the planning 
of social activities. The assistant principal explained this situation as follows:

"...Yes, there are student members at our social activities commission... the age group is significant. Suggestions do not come from these students... I do not believe that this commission can work at primary schools. As this is the case, we do not attempt to operate these commissions or carry out some things such as holding meetings. We organize them as documents..." (The Assistant Principal).

The students who were the members of the commission stated that they were not invited to participate in any meetings and that their views were not taken.

When these results were evaluated, it was detected that the realization level of children's right to participation in the social activities commission was "L0", and the arrangement phase was "Legal obligation".

\section{Children's Participation in the Process of Forming Homework}

The examinations carried out at the primary school which is highly qualified in terms of children's rights demonstrated that children were not involved in the formation process of homework. In the research, it was detected that teachers thought that they needed to decide on homework, and they, therefore, did not involve children in the process. One of the teachers commented on this situation as follows: "...I assign them the things they need as homework...This is not something that children must decide..."(Teacher 1). In the observations done in the classrooms, it was revealed that children's views were not taken in the process and that teachers assigned homework directly.

When the results are examined, it may be asserted that children's views were not sought in the formation process of homework. For this reason, the realization level of children's right to participation was "L0", and the arrangement phase was "non-existent". 


\section{Children's Participation in the Formation Process of Weekly Lesson Timetables}

Children's participation differed in the formation process of the weekly lesson timetables. In two classrooms, for example, children's views were taken when organizing the timetables (L3); in the other two classrooms, however, their views were not taken into consideration (L0).

When forming the weekly lesson timetables, the teachers who noted that they sought children's views believed that this could vary based on children's needs, and it was observed that they reflected this on their classroom practices. One classroom teacher stated the participation of children in the process of organizing lesson timetables as follows:

"I arrange the weekly lesson timetables. However, I act flexibly according to what students want. Children can come and tell this to me, and I try to consider it. I make new weekly or daily plans based on their desires. For example, I placed gaming and physical activities course into the last hours in the plans. But students sometimes state that they have got tired in the $4^{\text {th }}$ lesson. We can go out for physical education course at that lesson. We take that lesson to another day..." (Teacher, 3)

It was determined that the teachers who did not make changes according to children's desires in the weekly lesson plans thought that they could not make right decisions regarding the program and that children's desires would not give sound results.

The results showed that involving students in the process of forming the weekly lesson timetables was not a generally accepted value in the school and that children's participation could vary in different classrooms based on teachers' attitudes and beliefs.

\section{Children's Participation in the Process of Preparing the Classroom Bulletin Boards}

It was detected in the research that children participated in the process of preparing classroom bulletin boards in three classrooms at the primary school which is highly qualified in terms of children's rights, but children 
were not involved in this process in one classroom. In two of the classrooms in which children's participation was assured, the requests made by students were taken into consideration by teachers (L3). In one classroom, students were seen to have been involved in the decisionmaking process (L4). These teachers believed that classroom bulletin boards were the best application field for students to voice their views. Moreover, it was observed that some decisions regarding the topic choice and the materials to be pinned on the bulletin board were also made. In the preparation process, the teacher who stated that children's participation was not assured suggested that the board was not a functional thing and he made the decisions on his own. Additionally, it was seen that the teacher chose the materials to be pinned on the bulletin board as well.

The results revealed that the realization levels of children's right to participation were L0, L3, and L4 in the classrooms, and the arrangement phase ranged from "non-existent" to "opportunities" in the preparation process.

\section{Children's Participation in the Formation Process of the Classroom Rules}

In the research, three of the teachers noted that they involved students in the process of forming classroom rules. Furthermore, all of students' views were taken and then the rules were constructed. One of the teachers stated this situation as follows:

"At the beginning of the year, I wanted all of the students to express their views. We wrote all of them on the board respectively. We first discussed the rules and then put them to the vote. The ones accepted became our classroom rules. Of course, there were some rules which were not possible to be accepted; for example, one was that "Let's study the course for 30 minutes and become free in the rest of the time"... children want to play whenever possible. I did not accept the ones which were inapplicable after explaining the reason..." (Teacher, 4)

Students also confirmed their active participation in the process by noting similar statements to their teachers. One student asserted that: 
“...we made decisions by voting. In fact, our teachers asked us; we all stated the rules. Then he wrote them on the board; everyone explained his/her rule. We asked each other if they are significant. After that, we voted all of the rules one by one..." (S5, 4th grade)

The teacher of the first grade noted that she did not involve students in the process of forming the rules. The reason for this was that she thought that children were too young and they did not know what classroom or rule was. These results demonstrated that the realization level of children's right to participation was "L0" for the first grade, and it was L4 for other grades. The arrangement phases ranged between "non-existent" and "opportunities".

\section{Children's Participation in the Process of Planning the Free Activities Course}

The findings showed that all of the participating teachers paid attention to children's participation in the planning of the free activities course. Two of these teachers argued that they decided on the rules by voting, but they did not accept the rules which did not seem applicable and therefore changed the rules. One teacher commented:

“... I attempt to act based on students' choices in this course in order for students to acquire democratic values, use the right to choose and develop suggestions. However, children want to play outside even if the weather is too cold... It is impossible for me to accept this suggestion because they may get ill and their health may be badly affected. I, therefore, do not let them play outside." (Teacher, 3)

In the observations made in the classroom, it was determined that teachers actively involved students in the process. In this sense, they either made decisions based on the choices of the majority of the students or allowed students to make decisions individually. Children were observed to have tendency towards diverse activities such as reading books, playing chess and drawing in individually decided practices. 
Overall, it may be suggested that the realization level of children's right to participation was L4 and the arrangement phase was "opportunities" in the process of planning the free activities course at the primary school which is highly qualified in terms of children's rights.

\section{Children's Participation in the Process of Preparing School Bulletin Boards and The Board of Interesting Ideas}

In this research, it was determined that children were not involved in the decision-making process of organizing the bulletin boards directly; this was shaped by the school administration. However, the suggestions came from children were considered. For example, it was seen that children's views were taken in the arrangements regarding April 23 National Sovereignty and Children's Day. To this end, teachers worked in their classrooms, and they listened to students' views about what could be done. Afterwards, they came together and made decisions about visual materials, writings or designs to be used by paying attention to children's suggestions. Despite this, it was observed that there was a bulletin board which could enable students' active participation by directly coming up with ideas. The board was labeled as "The board of interesting ideas", and students arranged the board based on their own planning on a weekly basis.

The board was open for active participation of all of the students, and it was observed that students could make the arrangements they wanted and participated in the decision-making process directly. All of the grades had the chance to arrange this board in turn. However, the assistant principal stated that the arrangements made on the board were subjected to supervision and that the school administration did not allow the materials which could ruin children's psychology or involve political messages to be posted on the board. In terms of preparing the school's bulletin boards, the realization level of children's right to participation was L3, in terms of the board of interesting ideas, the realization level of children's right to participation was L4, and the arrangement phase was "opportunities".

\section{Children's Participation in the Arrangement of Playgrounds}

The school administration stated that children's views were not taken into consideration in the arrangement of the environment for playgrounds. They 
asserted that environmental arrangements were something that adults needed to do, and this issue could not be done by consulting children's views or decisions. The assistant principal stated that: “... We make such decisions as the management. I do not think that this requires children's participation. We try to do our best for them if possible... they are kids so they cannot think about these things in detail..."

It may be suggested that the realization level of children's right to participation was L0 in the process of constructing and arranging playgrounds, and the arrangement level was "non-existent".

\section{Children's Participation in the Process of Planning the Ceremonies}

It was revealed in the research that $2^{\text {nd }}, 3^{\text {rd }}$, and 4 th-grade students' participation was assured in the planning of the ceremonies. However, it was found out that the realization level of participation varied in different ceremonies. For example, in the ceremonies regarding certain days and weeks, the suggestions of children were taken into consideration, but they were directly involved in the decision-making process for April 23 National Sovereignty and Children's Day activities. In these activities, each grade made its own planning, and the plans made were transferred to the school level. In this process, students were asked to come up with ideas about the activities to be carried out either individually or as a whole class, and then they made decisions on the activities together.

The only grade whose direct participation was not assured in the planning of April 23 National Sovereignty and Children's Day activities (L0) was seen to be the first grade at the school. It was detected that the teacher of first graders determined the games and the poems on her own and made assignments accordingly. This teacher believed that the students were too young and therefore they could not make right decisions about what needed to be done at such arrangements.

The findings overall showed that the realization level of children's right to participation differed in the planning of the ceremonies at the school and that the level of realization of children's right to participation was L4 at three grades in the process of planning the April 23 National Sovereignty and Children's Day ceremony. It was also revealed that the children's right to participation level was L3 in three grades in other ceremonies, and the arrangement phases ranged between "non-existent" and "opportunities". 


\section{Children's Participation in the Process of Forming the School Rules}

Children's participation was not assured in the process of constructing school rules in the research. The school principal and the assistant principal stated that the school rules were constructed so as to put the operation of the school in an order and therefore children's views might not be consistent with the rules to be obeyed. Thus, they believed that involving children in the construction of the school rules might not be an appropriate approach.

The assistant principal commented:

"When constructing the school rules, we did not directly take students' views. To me, their participation in this process is not required... If it is up to them, the school must be without rules. Rules are the biggest power in our ensuring the order of the school. We cannot render this issue into a game for children... this may result in great problems." (The Assistant Principal)

The realization level of children's right to participation was L0, and the arrangement phase was "non-existent" in terms of constructing the school rules.

\section{Children's Participation in the Process of Arranging Teaching- Learning Activities}

Classroom observations and the interviews demonstrated that children were not involved in the arrangement process of teaching-learning activities. Teachers stressed that teaching process is a professional task, some arrangements must be done based on needs and these are not the issues children can decide on. One teacher stated that:

"I do not do this except for the free activities course. It is not appropriate since teaching is a professional job... namely, I do not do this personally. I choose suitable methods and techniques for their readiness. I try to teach them through more than one way. Can they know how they can learn best?" (Teacher, 3). 
In the classroom observations too, it was determined that teachers came to the classroom after making their planning, and they taught by adhering to the plans. Students were seen to have acted according to these plans.

It can be suggested based on the results that the realization level of children's right to participation in teaching-learning process was "L0", and the arrangement phase was "non-existent".

\section{Children's Participation in the Decision-Making Process Regarding the Issues Concerning Students}

In the research, it was seen based on the observations and interviews that students' participation was not assured in the decision-making process regarding the issues concerning them. The school administration and teachers stated that students' participation in the decision-making process regarding their education would not be appropriate because of the content of the topics and their ages. The classroom observations indicated that students' participation in the decision-making process regarding the issues concerning them was not ensured. To illustrate, one student's parent came to the school to meet one teacher for changing the student's school. They gave the decision regarding school change without consulting the student. Consistently, in the knowledge contest held among grades, the students to represent the grades were chosen by teachers, and students were only informed about their participation. The researchers were able to observe similar issues during the research process. Based on these results, it may be concluded that the realization level of children's right to participation was L0 in terms of the decision-making process regarding the issues concerning them, and the arrangement phase was "non-existent".

\section{Children's Participation in terms of Environmental Protection and Sustainable Development}

It was observed that some projects about environmental protection and sustainable development were carried out at school level, but these projects were planned by the school administration and teachers. Apart from this, both the school administration and teachers noted that they encouraged children's offering suggestions. 
The assistant principal explained this as follows:

"What have we done for protecting the environment? ... We are trying to raise an awareness about wastes. We have attended in a study of planting trees with children. Besides this, we had children to watch videos regarding saving water and the importance of the environment and water... We want students to offer ideas or projects, but they do not offer..." (The Assistant Principal)

The observations in the school also demonstrated that physical arrangements were made with the participation of children regarding environmental protection and sustainable development. For example, there were battery collection and recycling bins in the corridors, and there were also two posters related with environmental protection and sustainability pinned on one of the school bulletin boards. In the research, similar findings were obtained in the interviews conducted with teachers and classroom observations. Specifically, teachers were observed to have encouraged students to generate ideas about the importance of environmental protection and sustainable development and things could be done within science and life sciences courses.

When all of the results are considered, it may be asserted that the realization level of children's right to participation was L2 in terms of environmental protection and sustainable development, and the arrangement phase was "opportunities"

\section{Conclusion, Discussion, and Suggestions}

In this study, it was aimed to examine the level of realization of children's right to participation in a primary school which is highly qualified in terms of children's rights in Turkey. In line with this aim, what kinds of arrangements are made for the improvement of children's right to participation in a school the children's rights-based structure of which is high and the level of realization of children's right to participation were examined. In the present research, 15 different contexts were identified with regard to children's participation in the planning or decision-making processes at the primary school which is highly qualified in terms of children's rights. Among these contexts, it was determined that three 
arrangements requiring participation in the commissions or boards depended on legal regulations at national level. It was seen that children's participation was not assured in the executive committee on guidance and psychological counseling services and social activities commission directly. Although it was a legal requirement, it is interesting that children's participation was not ensured in these commissions. This result may result from the school administration's negative ideas and beliefs about the necessity of children's participation in these commissions and their functionality. In fact, it is a reality which cannot go beyond rhetoric when considered as a legal obligation or cultural enforcement. In a similar vein, it was observed that the school administration believed these commissions and councils to be dysfunctional and that only printed documents were prepared due to being a legal obligation. One of the most significant practices in terms of children's participation was the participation in the students' council (Hodgkin \& Newell, 1998; Inman \& Burke, 2002), which was seen to be much more functional when compared to other commissions. In this sense, it was revealed that students at the school knew that the students' council was a channel to communicate desires and complaints. In this context, it was stated that students report their requests to the students' council representative in school and that the SC representative reports them to the school administration. The students' council representative stated that their opinions were listened and taken into consideration by the school administration and teachers. However, the school administration stated that they evaluated children's requests, but they themselves made decisions. However, it can be stated that not assuring children's involvement in the decision-making processes in the commissions directly was a significant drawback. The problems faced with regard to children's participation in the students' council were also investigated by different researchers. In this sense, Cox and Robinson-Pant (2005), in their study on 5-11 aged students' participation in the school councils, argued that children's control and authority in making and implementing decisions was limited.

Another issue regarding children's participation was related with the formation of the rules. In the process of forming school and classroom rules, ensuring students' participation is a critical determinant for the construction of school culture, and this is a valuable factor for children's accepting and protecting the rules (Davies, Harber, \& Schweisfurth, 2005; 
Duman, Yavuz, \& Karakaya, 2016). In the formation of the classroom rules, students' participation was assured in all grade levels except for the first grade; however, students were not involved in the process of forming the school rules. In the study, it was determined that the reason why children were not included in the process of creating rules in the first grade was that they were considered to be too young and insufficient by their primary school teachers. Nevertheless, it is stated in the relevant literature that the active participation of children in the rule-making process should be taken as a basis even in the pre-school period (Durmuşoğlu Saltalı, \& Arslan, 2013). In this context, it can be said that failure to ensure the participation of children in the rule-making process at the first grade is a shortcoming. On the other hand, it can be said that the reason put forward by the teacher is a common view owned by the adults who prevent the realization of the right to participation of children at young ages (Ejieh \& Akinola, 2009). It was determined that children's participation in the process of forming the school rules was not regarded to be appropriate for the school order by the school administration. In this context, the school principal indicated that they excluded children from the process of creating school rules because they believed that children should not be involved in this process, that they considered school rules as the greatest power to ensure school order and believed that the inclusion of children in this process would pose a problem. Building on this result, it may be asserted that the school administration of the primary school which is highly qualified in terms of children's rights had some contrasting aspects with democratic school management. This situation may have stemmed from the hierarchical structure at the school. According to Johnny (2005), in many schools, there is a hierarchical structure which deprives students of participation in the process of producing ideas and rules, and the effect of adult stakeholders is more dominant in the process. In this way, children's right to participation cannot be realized democratically.

Teachers' and students' making plans together in the teaching-learning process is a significant issue in the construction of a democratic school (Apple \& Beane, 2007). In this research too, it was detected that students were directly involved in the planning of the free activities course. Students' participation in the planning of the free activities course is a critical aspect in terms of children's right to participation. This is also significant for the construction of democratic learning environments and 
improvement of educational quality. Likewise, in the Moswela (2010) study, it was found that teachers involved students in the decisions regarding instructional activities and that this made contributions to educational improvement and the construction of a democratic environment. Yamashita, Davies and Williams (2010) revealed that students' participation in the planning of the curricula and instructional methods made contributions to the curriculum, assessment and pedagogical development. However, in this study, it was unearthed that children were not involved in the planning of instructional activities except for the free activities course and formation of homework, which is a striking result. This may be viewed as a significant deficiency in terms of educational improvement, the construction of democratic learning environments and the realization of children's right to participation.

Children's participation in environmental protection and sustainable development is one of the issues regarding children's right to participation emphasized in the UN CRC (Hodgkin \& Newell, 1998). According to Hart (1997), planning, designing, organizing, and managing the physical environment is an ideal venue for children's participation, and children perceive the problems in these areas more clearly when compared to many societal problems. Within the context of the research, it was observed that various activities and projects were organized for children's participation in environmental protection and sustainable development at the primary school which is highly qualified in terms of children's rights. Nevertheless, it was revealed that children did not participate in the decision-making processes about the planning of the projects directly. When this case is considered in the light of the roles attributed to children's participation in environmental protection and sustainable development specified in the UN Convention on Children's Right to Participation, it can be seen that children's participation remained at low levels. Moreover, the results of the research showed that children's views were not taken into consideration in the planning of playgrounds and that they were not involved in the decision-making process about the construction of the school bulletin boards. When these results are considered with the findings obtained about children's participation in the process of constructing the school rules, it can be stated that children's participation in the school-level planning either was at a low level or did not occur at all. In addition, the results demonstrated that first graders' participation was more limited than that of 
other students. Similar results were obtained in the study by Horgan et al. (2017). Horgan et al. noted that younger participants were not involved in the decision-making processes at their schools. At the same time, they found that power balance at schools had negative impacts on children's participation and that children's age and competencies are critical factors for their participation. Furthermore, Horgan et al. determined that children's views were not taken in the process of forming lesson plans. Similarly, in this study, it was determined that the opinions of children were not received in the process of creating a curriculum in the second and fourth grades. Teachers' beliefs that they could make the right decisions for the program and the fact that they thought children's requests would not give positive results since they are young were determined to be effective on this decision made. Another significant finding of the research was linked with children's participation in the decision-making processes regarding the issues concerning them. In this context, it was determined that children's opinions were not generally received in the decisions related to the education process at any grade level and that student's parents were communicated when necessary. It was determined that this was due to the teachers' and school administration's thought that the participation of children in the decision-making process in the issues related to them would not be appropriate because of the decisions taken and their age. In their study, Polat and Gezer (2007) examined the ratios of 7-18 aged children's right to speak pertaining to decisions about themselves. They revealed that the ratios of children's right to speak was rather low both at home and schools. This study unearthed consistent results about the primary school which is highly qualified in terms of children's rights.

On the other hand, enacting children's rights in real life requires a children's rights-based school culture (Lansdown et al., 2014). In order for the realization of children's right to participation, a school culture which promotes children's right to participation is needed. In the present research, it was revealed that the types and realization level of the arrangements made in the classroom with regards to children's right to participation seemed to have varied. The school administration did not partially support children's participation in the decision processes at school level. This result may be interpreted that children's right to participation did not emerge as a shared value in the school culture of the school which could direct school policy and practices. 
When the results of the research are evaluated overall, it can be asserted that the arrangements about children's right to participation at the primary school which is highly qualified in terms of children's rights could not be built in a way to embrace the whole school culture. The scope of the arrangements at the first grade was narrower, and from among the legal obligations, children's participation was only ensured in the students' council. In line with these results, it can be said that the values and beliefs of teachers and school administration play a determining role in the implementation of children's right to participation. It is thought that the results of this study contribute to the current knowledge base from these perspectives. Research results provide detailed information on the best practices implemented in primary schools for children's right to participation in Turkey and accordingly the diversity, qualities, and shortcomings of the arrangements. In this respect, it can be said that they constitute important data for comparative studies in the international context. Furthermore, information on the values and beliefs that are effective in the realization of children's right to participation was achieved in the study. In this context, it is thought that they will contribute to the formation of knowledge in the international literature for determining the factors affecting the implementation of children's right to participation. In general, the study also provides information on well-functioning arrangements and the problems and shortcomings experienced in a school which is highly qualified in terms of children's rights. Accordingly, it is thought that it will also contribute for the studies to be carried out for the implementation of children's right to participation. The results of the research, it is recommended that in-service training must be provided for teachers and administrators and that studies which may facilitate children's participation in the decision-making and planning processes should be conducted.

\section{Notes}

This study is based on master's thesis titled "An Analysis of Children's Right to Participation at Primary Schools in Turkey: A Case Study"

1 PL: Participation Levels **APC: The arrangement phase for children's right to participation $* * * N E$ : Non-existent $* * * * O P$ : Opening $* * * * * O$ : Opportunities $* * * * * * L O$ : Legal Obligations 


\section{References}

Apple, M. W., \& Beane, J. A. (2007). Democratic schools: Lessons in powerful education. Portsmouth NH: Heinemann

Burger, K. (2018). The subjective importance of children's participation rights: A discrimination perspective. American Journal of

Orthopsychiatry, 1-31. Retrieved from

http://psycnet.apa.org/buy/2018-35600-001

Cotmore, R. (2003). Organisational competence: the study of a school council in action. Children \& Society, 18(1), 53-65. doi:10.1002/chi.786

Covell, K., Howe, R. B., \& McNeil, J. K. (2010). Implementing children's human right education in schools. Improving Schools, 13(2), 117132. doi: $10.1177 / 1365480210378942$

Cox, S., \& Robinson-Pant, A. (2005). Challenging perceptions of school councils in the primary school. Education, 3-13(33:2), 14-19. doi:10.1080/03004270585200161

Davies, L., Harber, C., \& Schweisfurth, M. (2005). Democratic professional development. Birmingham: CIER/CfBT.

Davies, L., Williams, C., Yamashita, H., \& Ko Man-Hing, A. (2006). Inspiring schools impact and outcomes: Taking up the challenge of pupil participation. London: Carnegie UK Trust; EsmeeFairbairn.

Duman, T., Yavuz, N., \& Karakaya, N. (2016). Insan haklarl ve demokrasi vatandaşlık bilgisi [Human rights and democracy, knowledge of citizenship]. Ankara: Pegem Akademi

Durmuşoğlu Saltal1, N., \& Arslan, E. (2013). The rules pre-school teachers establish for their classes and their application. Elementary Education Online, 12(4), 1032-1040. Retrieved from http://dergipark.ulakbim.gov.tr/ilkonline/article/view/5000037741/50 00036599

Ejieh, M.U.C., \& Akinola, O.B. (2009). Children's rights and participation in schools: Exploring the awareness level and views of Nigerian primary school children. Elementary Education Online, 8(1), 176182. Retrieved from http://dergipark.gov.tr/download/articlefile/90899

Flowers, N., Santos, M. E. B., Claeys, J., Fazah, R., Schneider, A., \& Szelényi, Z. (2009). Campasito: manual on human rights education 
for children. Retrieved from

http://www.eycb.coe.int/compasito/pdf/Compasito\%20EN.pdf

Gilleece, L., \& Cosgrove, J. (2012). Student civic participation in school:

What makes a difference in Ireland?. Education, Citizenship and

Social Justice, 7(3), 225-239. doi:10.1177/1746197912448715

Habashi, J. S., Driskill, T., Lang, J. H., \& De Falco, P. L. (2010).

Constitutional analysis: A proclamation of children's right to protection, provision, and participation. International Journal of Children's Rights, 18, 267-290.

doi:10.1163/157181809X12615514762046

Hart, C. S., \& Brando, N. (2018). A capability approach to children's wellbeing, agency and participatory rights in education. European Journal of Education, 53(3), 293-309 doi:10.1111/ejed.12284

Hart, R. (1997). Children's participation: The theory and practice of involving young citizens in community development and environmental care. London: Earthscan, Unicef.

Hodgkin, R., \& Newell, P. (1998). Implementation handbook for the convention on the rights of the child. New York: UNICEF.

Horgan, D., Forde, C., Martin, S., \& Parkes, A. (2017). Children's participation: Moving from the performative to the social. Children's Geographies, 15(3), 274-288. doi:10.1080/14733285.2016.1219022

Howe, R. B., \& Covell, K. (2007). Empowering children: Children's rights education as a pathway to citizenship. Toronto: University of Toronto Press

Howe, R. B., \& Covell, K., (2010). Miseducating children about their rights. Education, Citizenship and Social Justice, 5(2), 91-102 doi:10.1177/1746197910370724

Inman, S., \& Burke, H. (2002). School councils: an apprentice ship in democracy?. London: Association of Teachers and Lecturer

Johnny, L. (2005). UN Convention on the rights of the child: A rationale for implementing participatory rights in schools. Canadian Journal of Educational Administration and Policy, 40. Retrieved from https://journalhosting.ucalgary.ca/index.php/cjeap/issue/view/2944

Koran, N., \& Avc1, N. (2017). Perceptions of prospective pre-school teachers regarding children's right to participate in classroom activities. Educational Sciences: Theory and Practice, 17(3), 10351059. Retrieved from http://www.estp.com.tr/article/perceptions-of- 


\section{prospective-pre-school-teachers-regarding-childrens-right-to- participate-in-classroom-activities/}

Lansdown, G. (2010). The realisation of children's participation rights:

Critical reflections. In B. Percy-Smith \& N. Thomas (Eds.), A handbook of children and young people's participation. Perspectives from theory and practice (pp. 11-23). London: Routledge.

Lansdown, G. (2011). Every child's right to be heard. A resource guide on the UN committee on the rights of the child general comment no.12. Retrieved from

https://www.unicef.org/french/adolescence/files/Every_Childs_Right _to_be_Heard.pdf

Lansdown, G., Jimerson, S. R., \& Shahroozi, R. (2014). Children's rights and school psychology: children's right to participation. Journal of School Psychology, 52(1), 3-12. doi:10.1016/j.jsp.2013.12.006

Lloyd, K., \& Emerson, L. (2017). (Re)examining the relationship between children's subjective wellbeing and their perceptions of participation rights. Child Indicators Research, 10(3), 591-608. Retrieved from https://link.springer.com/article/10.1007/s12187-016-9396-9

Miles, M. B., \& Huberman, A. M. (1994). Qualitative data analysis: An expanded sourcebook (2nd ed.).Thousand Oaks \& London: Sage Publication

Miller, J. (1997). Never too young. London: National Early Years Network.

Moore, L., \& Kirk, S. (2010). A literature review of children's and young people's participation in decisions relating to health care. Journal of Clinical Nursing, 19(15-16), 2215-2225. doi:10.1111/j.13652702.2009.03161.x

Moswela, B. (2010). Democratic education in the classroom: An education law perspective. Journal of Education Administration and Policy Studies, 2(4), 56-62. doi:10.5897/IJEAPS09.049

Osler, A., \& Starkey, H. (2005). Changing citizenship: Democracy and inclusion in education. Maidenhead: Open University Press

Öztürk, A. (2017). Türkiye'de hayat bilgisi dersi öğretim programlarında çocukların katılım hakkı: Tarihsel bir analiz [Children's participation rights in the life sciences curricula in Turkey: A historical analysis]. Adıyaman Üniversitesi Sosyal Bilimler Enstitüsü Dergisi, 27, 864890. doi:10.14520/adyusbd.329894 
Öztürk, A., \& Doğanay, A. (2017). Çocuk hakları temelli okul ölçeğinin geliştirilmesi [Developing the children's right based school scale]. Trakya Üniversitesi Sosyal Bilimler Dergisi, 19(1), 41-58 Retrieved from http://dergipark.gov.tr/download/article-file/336876

Pascal, C., \& Bertram, T. (2009). Listening to young citizens: The struggle to make real a participatory paradigm in research with young children. European Early Childhood Education Research Journal, 17(2), 249-62. doi:10.1080/13502930902951486

Patton, M. Q. (2002). Qualitative research \& evaluation methods. Thousand Oaks, CA: Sage.

Perry-Haza, L. (2016). Children's participation in national policymaking: "You're so adorable, adorable, adorable! I'm speechless; so much fun!'. Children and Youth Services Review, 67,105-113. doi:10.1016/j.childyouth.2016.05.015

Polat, O., \& Gezer, T. (2007). Sosyal içerme ve çocukların katılım hakkı [Social inclusion and children's participation rights]. İstanbul: Kaynak Kitap Dizisi.

Raby, R. (2014). Children's participation as neo-liberal governance? Discourse: Studies in the Cultural Politics of Education, 35(1), 7789. doi:10.1080/01596306.2012.739468

Roberts, H. ( 2003). Children's participation in policy matters. In C. Hallett \& A. Prout (Eds.), Hearing the voices of children: Social policy for a new century (pp. 26-37). London: RoutldegeFalmer.

Rudduck, J., \& Flutter, J. (2000). Pupil participation and pupil perspective: Carving a new order of experience. Cambridge Journal of Education, 30(1), 75-90. doi:10.1080/03057640050005780

Shier, H. (2001). Pathways to participation: Openings, opportunities and obligations. Children and Society, 15(2), 107-117. doi:10.1002/chi.617

Smith, A. B. (2007). Children and young people's participation rights in education. The International Journal of Children's Rights, 15(1), 147-164. Retrieved from http://booksandjournals.brillonline.com/content/journals/10.1163/092 $755607 \times 181739$

Strauss, A., \& Corbin, J. (1990). Basic of qualitative research: Grounded theory procedures and techniques. Newbury Park and London: Sage. 
Synodi, E. (2014). Children's rights and the operation of Greek kindergartens. International Education Journal: Comparative Perspectives, 13(2), 60-72. Retrieved from https://openjournals.library.sydney.edu.au/index.php/IEJ/article/view 17626

Tozduman Yaralı, K., \& Güngör Aytar, F. A. (2017). Okul öncesi sınıflarında çocuğun katılım hakkının çocukların ve öğretmenlerin görüşlerine göre incelenmesi [Investigate the participation rights of children into the preschool classes through teachers and children views]. Bartin University Journal of Faculty of Education, 6(1), 2947 Retrieved from http://dergipark.gov.tr/download/articlefile/230075

Yamashita, H., Davies, L., \& Williams, C. (2010). Assessing the benefits and impacts of participation. In: S. Cox, A. Robinson-Pant, C. Dyer, $\&$ M. Schweisfurth (Eds.), Children as decision makers in education (pp. 99-108). London: Continuum

Yin, R. K. (2009). Case study research: Design and methods. Sage Publications.

Ahmet Kılıç is Lecturer in the Vocational School of Health Services at the Bozok University, Turkey.

Ayşe Öztürk is Assistant Professor in Department of Primary Education at Faculty of Education at Gaziantep University, Turkey. ORCID, id: 00000001-9279-1716

Contact Address: Ayşe Öztürk, Gaziantep Üniversitesi, Osmangazi Mahallesi, Üniversite Blv. 27310 Şehitkamil/Gaziantep, Turkey.. Email: ozturkayse2007@gmail.com 